Ann. Biol. anim. Bioch. Biophys., 1978, 18 (2 B), 503-509.

\title{
Hormonal dynamics in the preovulatory ovarian follicle and the oocyte in rat during proestrus
}

\author{
by Stanislawa STOKLOSOWA, Maria SZOLTYS \\ with the technical assistance of Mrs Eva GREGORASZCZUK
}

Dept. of Animal Physiology, Institute of Zoology,

Jagiellonian Universify, ul. Krupnicza 50, 30-060 Kraków, Poland.

Summary. We studied functional and morphological luteinization of granulosa cells in intact preovulatory follicles and in cultured granulosa cells collected from the proestrous follicles of the rat.

Steroid hormones were measured by radioimmunoassay in follicles dissected from the ovaries every $2 \mathrm{hrs}$ on the day of proestrus beginning at 8:00 hrs and terminating at the time of ovulation. Granulosa cells for culture were collected in the same intervals. We simultaneously observed the morphology of granulosa cells and follicle-enclosed oocytes in vivo.

Follicles secreted estrogens throughout protstrus until 20:00 hrs. Progestin increased to maximum levels at 18:00 hrs. At the same time meiotic division in the oocytes of preovulatory follicles was observed. At 24:00 hrs, the granulosa cells of the corona radiata and cumulus morphologically resembled luteal cells.

\section{Introduction.}

The growing ovarian follicle is the site of many important and complex phenomena leading to the processes of ovulation and subsequent luteinization. The interaction between the particular components of the follicle is of interest, and especially that between granulosa cells and the oocyte during the most dynamic phase, proestrus.

Several papers have been published suggesting the inhibitory role of the oocyte on luteinization of granulosa cells (El-Fouly et al., 1970 ; Nekola and Nalbandov, 1971 ; Stoklosowa and Nalbandov, 1972). In all these investigations, follicles containing germinal vesicle oocytes were studied before resumption of ovum maturation.

More recent experiments (Noworyta and Szoltys, 1975 ; Szoltys, 1976) have shown that proestrus follicles (mainly granulosa cells) are the source of preovulatory progesterone increase in rat at $18: 00$ hrs on the day of proestrus.

The aim of the present experiment is to investigate the appearance, hormonal activity and possible luteinization of granulosa cells in preovulatory follicles in rat in vivo and in tissue culture. Oocyte change was studied in an in vivo experiment. 


\section{Material and methods.}

Fifty to 60-day old Wistar female rats were used. The animals were exposed to $12: 12$ light/dark hours; they showed a regular 4-day cycle determined by vaginal smear technique. Most females ovulated between 2:00 and 4:00 hrs. In all experiments presented here, follicles and granulosa cells were collected at 8:00, 11:00, 14:00, $16: 00,18: 00,20: 00,22: 00,24: 00$ and $2: 00$ hrs, just before ovulation.

Follicles and steroid analysis. - In one group of animals, the large follicles were isolated manually under the dissecting microscope at the intervals mentioned above, then homogenized in phosphate buffer. Estrogens were estimated by means of a RIA (Hotchkiss et al., 1971). Progesterone was measured by a PBA previously described by Szoltys (1976).

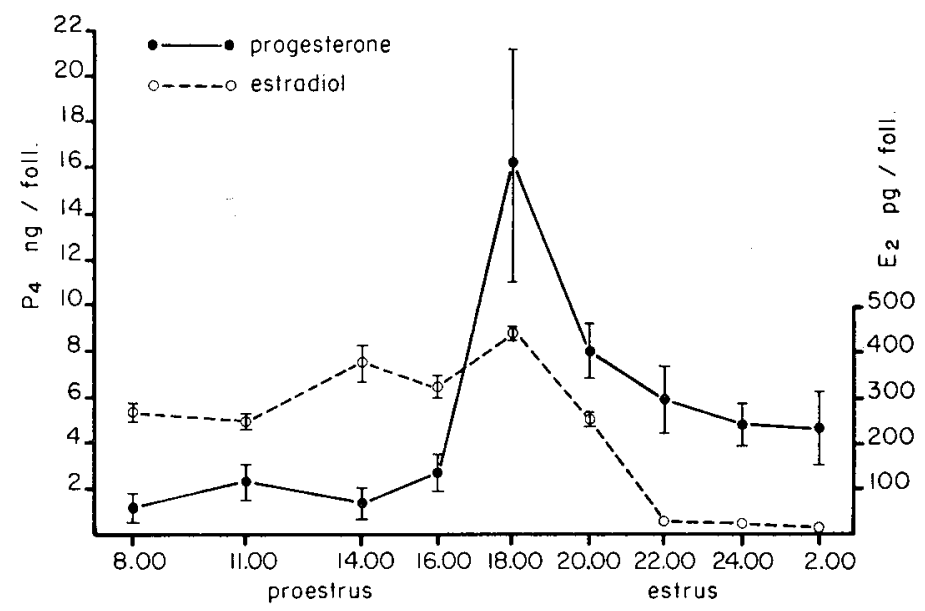

FIG. 1. - Estrogen and progestin dynamics in rat preovulatory follicles during proestrus. Concentration is expressed in $\mathrm{ng}$ or pg per follicle.

Histological observation. - Whole ovaries were dissected at the hours given above and then processed for histological examination using Bouin fluid as a fixative and hematoxylin and eosin staining. The morphology of the oocytes was compared

FIG. 2. - A monolayer of rat granulosa cells collected at 24:00 hrs; 4-day culture. May-GrünwaldGiemsa stan $(\times 128)$.

FIG. 3. - Histochemical demonstration of $\Delta^{5}, 3 \beta \mathrm{OH}$ SDH octivity in cultured cells collected from large follicles at 8:00 hrs on the day of proestrus ; 4-day culture $(\times 128)$.

FIG. 4. - Enzyme activity in granulosa cells collected at 14:00 hrs the days of proestrus ; 4-day culture $(\times 128)$.

FIG. 5. - A colony of rat granulosa cells collected for culture ot 16:00 hrs. Cells were histochemically tested for enzyme activity on day 4 of culture $(x 38)$. 

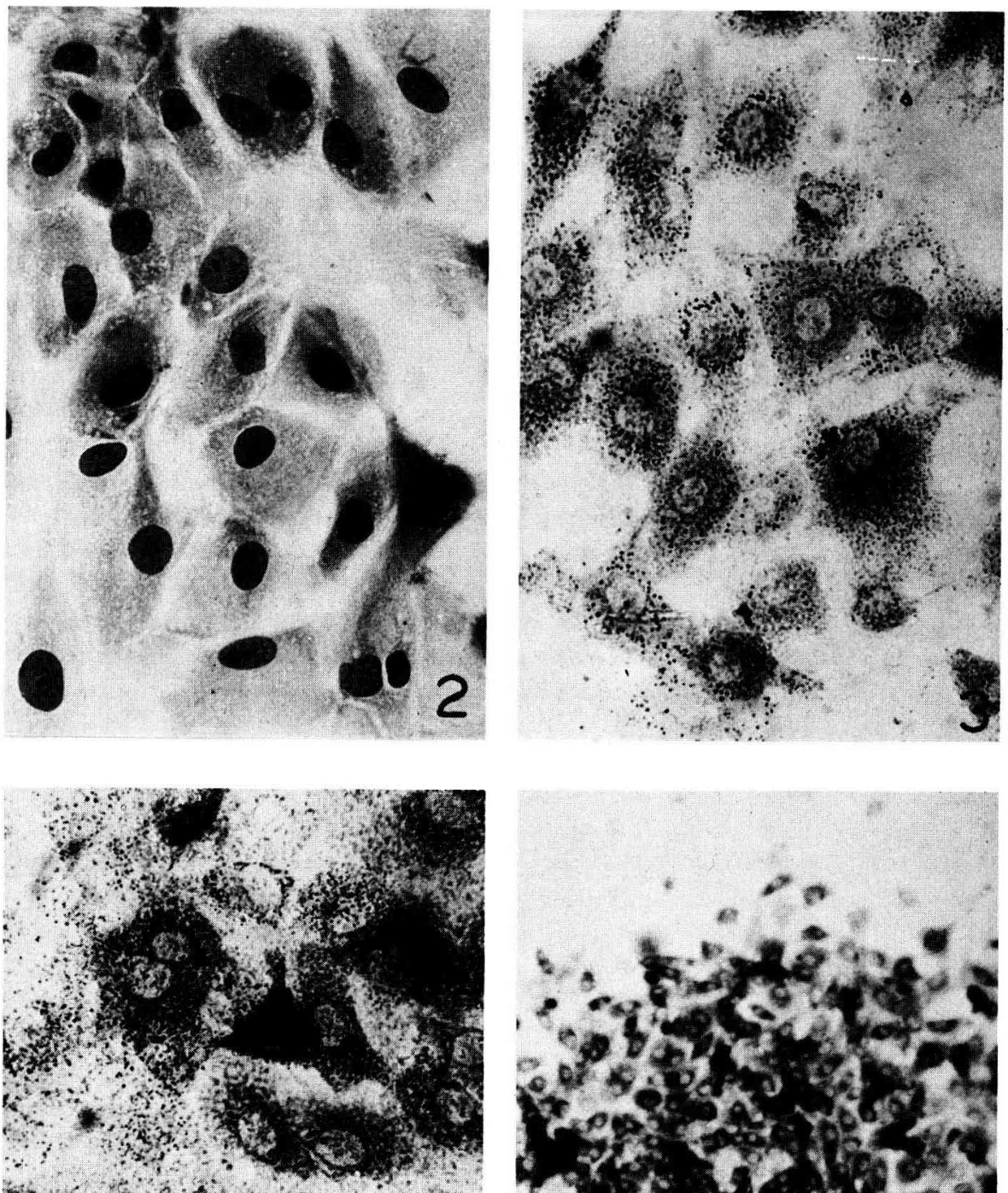

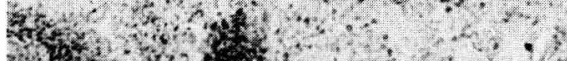
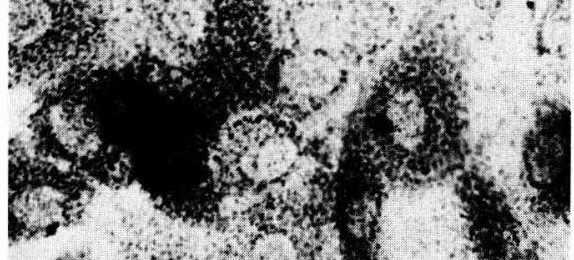

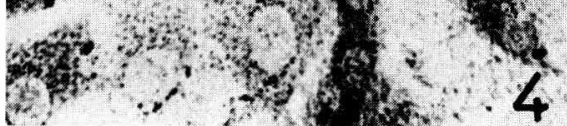

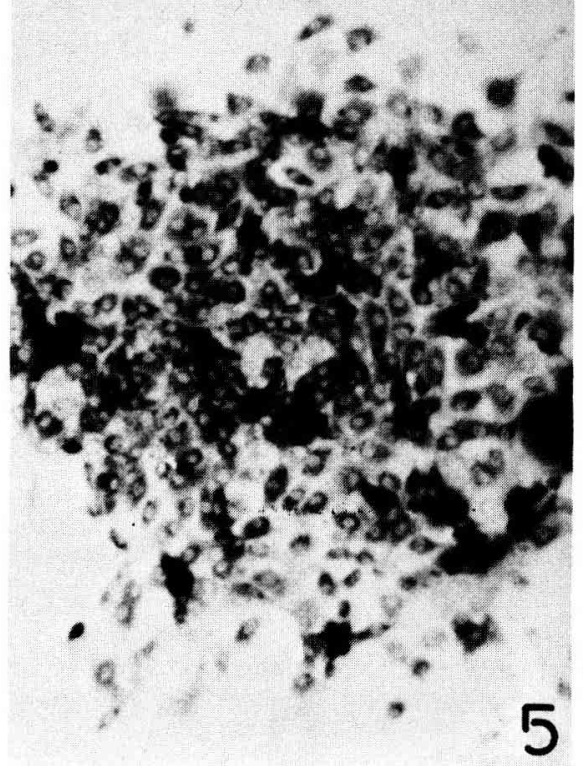


with the pictures published by Baker (1972), Lindner ef al. (1974) and Vermeiden and Zeilmaker (1974).

Tissue culture. - A third group of animals was used as a source of granulosa cells. Proestrus animals were killed at the times given above and the large follicles were punctured by a very thin intradermal injection needle; granulosa cells were sucked into a $1 \mathrm{ml}$ syringe confaining $0.1 \mathrm{ml}$ of Eagle culture medium enriched with a $10 \mathrm{p} .100$ concentration of calf serum. The granulosa cells collected from the large follicles of one ovary were inoculated into one culture tube. Cells were grown as monolayers in Leighton tubes (fig. 2) during 4-6 days. In order to show steroidogenic activity of cultured cells, a histochemical test for the detection of $\Delta^{5}, 3 \beta \mathrm{OH}$ SDH enzyme was performed (Noworyta and Szoltys, 1975).

\section{Results.}

Estrogen and progestin dynamics in preovulatory follicles are shown in figure 1. Estrogen secretion maintained a rather high level of 250 picograms between 8:00 to 11:00 hrs, over $300 \mathrm{pg}$ at 14:00 hrs, and a maximum $440 \mathrm{pg}$ at 18:00 hrs. Afterwards, a drastic decline of estrogen levels was observed. On the other hand, progesterone secretion during the morning and noon of proestrus was very low (fig. 1 and Szoltys, 1976). At 16:00 hrs progesterone secretion began to increase and reached a maximum at 18:00 hrs; it declined shortly afterwards. Progesterone secretion, however, did not drop back to the levels observed in the morning. Granulosa cells in culture exhibited $\Delta^{5}, 3 \beta$ OH SDH activity, but the intensity of the histochemical reaction depended on the time of cell harvest. The most intense enzymatic activity appeared in cells collected at 11:00, 14:00 and 16:00 hrs (figs. 4,5) ; this was not found in the morning (fig. 3) or evening follicles. At 24:00 hrs, enzymatic activity increased slightly. This investigation is being continued and we will have more quantitative data in the future. Histological observation of the in vivo follicles showed that between 8:00 and 18:00 hrs on the day of proestrus there were no marked changes in the large oocytes. Germinal vesicles were present in the oocytes of normal Graafian follicles (fig. 6). At 18:00 hrs meiotic figures were observed in the oocytes. During that time no morphological changes were seen anywhere in the granulosa layer. At 24:00 hrs we noted an interesting phenomenon. The granulosa cells of the corona radiata and those of the cumulus enlarged and became acidophilic around oocytes which had extruded the polar body; they resembled luteal cells in shape (fig. 7). This phenomenon was also observed for the granulosa cell layer in contact with the antrum of the follicle (fig. 8). At 2:00 hrs, the cells of the corona had become looser and scattered around the oocyte.

\section{Discussion.}

In former (Noworyta and Szoltys, 1975 ; Szoltys, 1976) and present experiments, it has been shown that granulosa cells in the preovulatory follicle were functionally luteinized since they could secrete large amounts of progesterone before ovulation. This phenomenon was preceded by increased $\Delta^{5}, 3 \beta \mathrm{OH} \mathrm{SDH}$ activity stimulated by preovulatory gonadotropin release. This functional luteinization was, however, not 

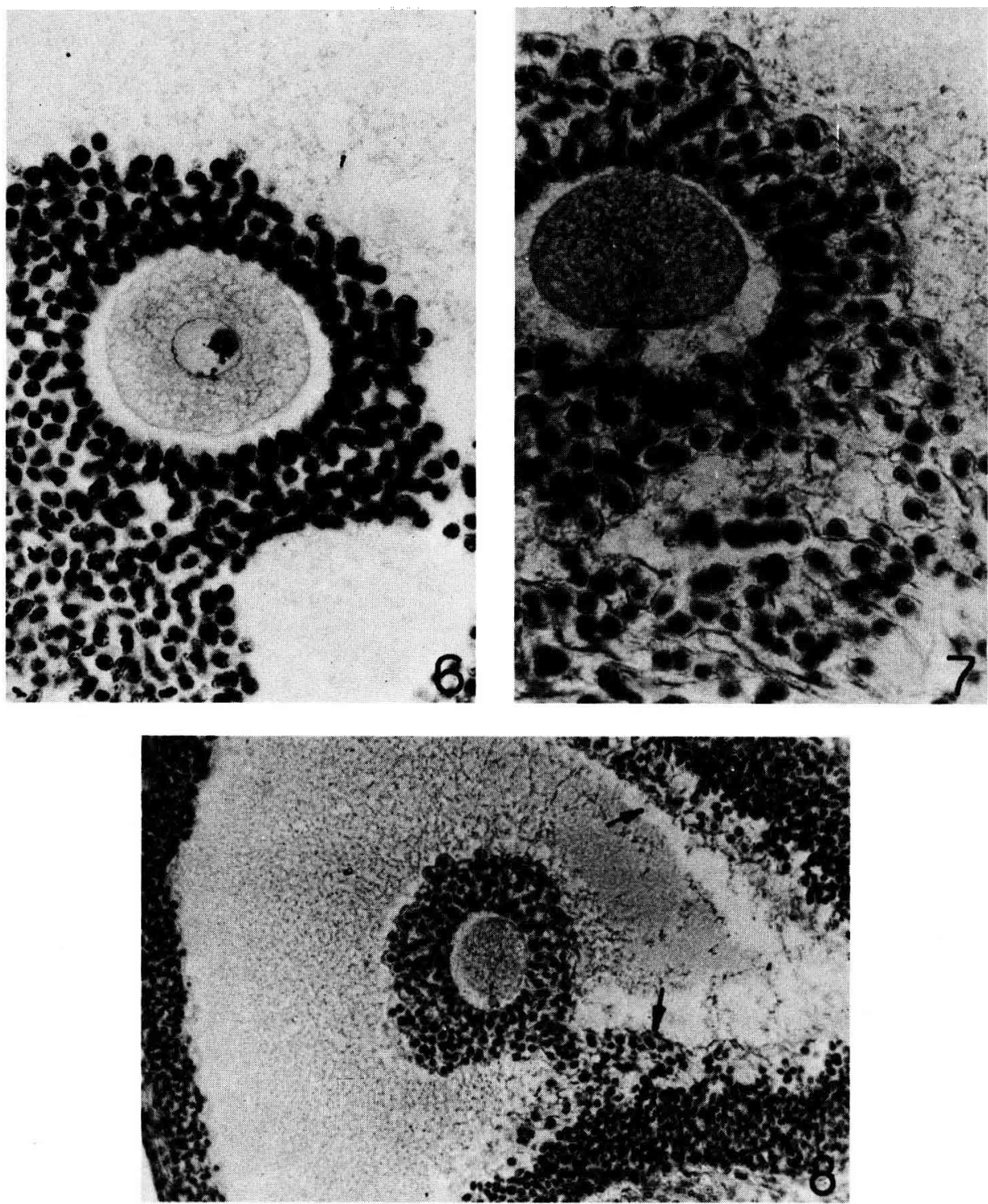

FIG. 6. - An oocyte and surrounding granulosa cells in a follicle of 14:00 hrs of proestrus; hematoxylin and eosin staining $(\times 128)$.

FIG. 7. - An oocyle and corona cells of 24:00 hrs showing o polor body; hematoxylin and eosin staining $(\times 128)$.

FIG. 8. - A preovulatory follicle at 24:00 hrs. Nests of luteal cells visible in the mural cumulus and in the antral region ; hematoxylin and eosin staining $(\times 51)$. 
expressed by the simultaneous morphological luteinization of granulosa cells, which only appeared at 24:00 hrs. A similar morphological phenomenon was observed by Norman and Greenwald (1972) in hamster 2-3 hrs before ovulation. At that time, hardly any estrogen was found in the rat follicle (fig. 1). It is difficult to say whether luteinization before preovulatory LH increase is blocked (i) by the inhibitory substance which Channing and Ledwitz-Rigby (1975) found in the follicular fluid of small follicles in pig, (ii) by the inhibitory action of the oocyte itself (El-Fouly et al., 1970), or (iii) by the granulosa exerting an inhibitory influence upon oocyte maturation (Foote an Thibault, 1969). It is interesting that granulosa cells isolated from rat follicles and cultured separately seem to be affected by the time of their removal from the follicle. Rat granulosa cells in vivo and in vitro showed similar enzymatic patterns. There is also evidence (Madej, unpublished data) that LH markedly stimulates $\Delta^{5}, 3 \beta, \mathrm{OH} \mathrm{SDH}$ activity when added to the medium of cultured granulosa cells harvested from follicles at 11:00,14:00 and 16:00 hrs of the proestrus phase. These times coincide with the preovulatory gonadotropin maximum in vivo.

Nalbandov and his co-workers explained the absence of luteinization in follicles containing healthy and viable oocytes. However, in all these experiments, oocytes in investigated follicles did not show any maturation division. It is possible that at this stage the oocyte could inhibit luteinization, and that when it entered meiotic division if lose its inhibitory capacity. On the other hand, Lieberman ef al. (1976) did not observe any influence of ovectomy in rat on progesterone secretion in culture. However, ovectomy of such small follicles could be injurious and cause atresia instead of luteinization of these follicles. It is hard to explain this discrepancy with our present knowledge on luteinization.

From this experiment it is evident that granulosa cells in proestrus progressively mature hormonally and that LH stimulation causes them to luteinize functionally. Morphological luteinization seems to be a consequence of functional luteinization. At the same time, maturation processes continue in the oocyte. Whether these two phenomena are completely independent in vivo as Liberman showed in vitro needs to be further investigated.

\section{Conclusions.}

1. Granulosa cells in proestrus follicles first undergo functional luteinization and then a part of them « luteinizes » morphologically.

2. There is almost no estradiol found at the time of morphological « luteinization » of corona and cumulus cells.

3. Granulosa cells explanted from large follicles at proestrus and cultured in vitro maintain the characteristics observed in vivo.

$27^{\mathrm{e}}$ Congrès international des Sciences physiologiques, Symposium « Germ and somatic cell interaction 》 Paris, 21-23 juillet 1977. 
Acknowledgments. - The antiserum used in these experiments was kindly donated by Dr. B. Caldwel, Yale University, USA and by Professor Dr. H. Lindner and Dr. F. Kohen, Weizman Instifute, Rehovot, Israel.

This investigation was supported by NIH PL 480 Research Agreement No 05001-0, Annex 05-040-N and the WHO Small Supply Program.

Résumé. Nous avons étudié la lutéinisation morphologique et fonctionnelle des cellules de la granulosa dans les follicules préovulatoires et dans des culłures de cellules prélevées dans des follicules de ratte au prostrus.

Le dosage radioimmunologique des stéroïdes est réalisé dans les follicules prélevés toutes les deux heures à partir de $8 \mathrm{~h}$ le jour du prostrus jusqu'au moment de l'ovulations. Les cellules de granulosa pour les cultures sont prélevées aux mêmes moments. Les follicules ovariens sécrètent de l'estradiol jusqu'à $20 \mathrm{~h}$ du prostrus, la concentration de la progestérone atteint un maximum à $18 \mathrm{~h}$. C'est le moment où apparaissent les premières divisions de maturation dans les ovocytes. A minuit les cellules de la granulosa et du cumulus sont morphologiquement lutéinisés.

Les cellules de granulosa cultivées in vitro montrent une activité $\Delta 5,3 \beta$ OH SDH dont l'intensité varie avec le moment du prélèvement. L'activité la plus intense est observée pour les prélèvements faits à 14 et $16 \mathrm{~h}$ du prostrus.

\section{References}

BAKER T. G., 1972. Oogenesis and ovulation, 14-15. In AUSTIN C. R., SHORT R. V., Reproduction in mammals, 1. Germ Cells and Fertilization. Univ. Press, Cambridge.

CHANNING C. P., LEDWITZ-RIGBY F., 1975. The corpus luteum studied in vitro, 353-370. In COUTINO E. M., FUCHS F., Physiology and genetics of reproduction, part B, Plenum Publ. Corp., New York

EI-FOULY M. A., COOK B., NEKOLA M. V., NALBANDOV A. V., 1970. Role of the ovum in follicular luteinization. Endocrinology, 87, 288-293.

FOOTE W. D., THIBAULT C., 1969. Recherches expérimentales sur la maturation in vitro des ovocytes de truie et de veau. Ann. Biol. anim. Bioch. Biophys., 9, 329-349.

HOTCHKISS J., KNOBIL E., ATKINSON L. E., 1971. Radioimmunoassay of estradiol is small volumes of peripheral plasma. Endocrinology, 89, 177-183.

LIEBERMAN M. E., TSAFRIRI A., BAUMINGER S., COLLINS W. P., AHRÉN K., LINDNER H. R., 1976. Oocytic meiosis in cultured rat follicles during inhibition of steroidogenesis. Acta endocrinol., 83, 151-157.

LINDNER H. R., TSAFRIRI A., LIEBERMAN M. E., ZOR U., Y., BAUMINGER S., BARNEA A., 1974. Gonadotropin action on cultured Graafian follicles : induction of maturation division of the mammalian oocyte and differentiation of luteal cell. Recent Progr. Horm. Res., 30, 79-138.

NEKOLA M. V., NALBANDOV A. V., 1971. The influence of the ovum on the appearance of granulosa cells grown as monolayers. Biol. Reprod., 4, 154-147.

NORMAN R. L., GREENWALD G. S., 1972. Follicular histology and physiological correlates in the preovulatory hamster. Anat. Rec., 173, 95-108.

NOWORYTA B., SZOLTYS M., 1975. Dynamics of the $\Delta^{5}, 3 \beta$ OH SD activity in rat follicular granulosa cells during proestrus. Bull. Acad. pol. Sci., Sér. Sci. biol., Cl. V. XXIII, 65-69.

STOKLOSOWA S., NALBANDOV A. V., 1972. Luteinization and steroidogenic activity of rat ovarian follicles cultured in vitro. Endocrinology, 91, 25-32.

SZOLTYS M., 1976. Progestagen dynamics in preovulatory follicles of rats. J. Reprod. Fert., 48, 397-398.

VERMEIDEN J. P. W., ZEILMAKER G. H., 1974. Relationship between maturation division and luteinization in the female rat. Endocrinology, 96, 341-351. 